\title{
PENGELOLAAN USAHA PERTAMBANGAN MINERAL DAN BATUBARA PASCA BERLAKUNYA UNDANG- UNDANG NOMOR 11 TAHUN 2020 TENTANG CIPTA KERJA
}

\author{
Desman Diri Satriawan
}

Fakultas Hukum Universitas Lampung

Email: desmandiri.satriawan@gmail.com

\begin{abstract}
Mining is part or all of the stages of activities in the context of research, management, and exploitation of minerals or coal which include general investigation, exploration, feasibility studies, construction, mining, processing and refining, transportation and sales, as well as post-mining activities. the government has the authority in mining management but in practice, the government itself is actually not able to carry out mining business on these natural resources. So that to carry out these activities, the government gives authority to other parties to be able to carry out mining business on mining natural resources. The presence of Law 11 of 2020 concerning Job Creation is expected to be a solution, especially regarding the convoluted and overlapping licensing and bureaucratic issues. The purpose of writing is to find out how to manage mineral and coal mining businesses after the enactment of law number 11 of 2020 concerning job creation, and the impact of management of mineral and coal mining businesses after the enactment of law number 11 of 2020 concerning job creation. This research is a normative legal research that uses legal materials and non-legal materials by using a statutory approach and conceptual approach and produces a descriptive, analytical, juridical study. It is concluded that the mining business itself is carried out based on a business license from the central government where the business license is carried out through the provision of business registration numbers, standard certificates and permits. The impact of the impact of the management of the mineral and coal mining business after the enactment of Law Number 11 of 2020 concerning Job Creation, among others, has an impact on the environment and social.
\end{abstract}

Keywords: mining business, environment, social.

\begin{abstract}
Abstrak
Pertambangan merupakan sebagian atau seluruh tahapan kegiatan dalam rangka penelitian, pengelolaan, dan pengusahaan mineral atau batubara yang meliputi penyelidikan umum, eksplorasi, studi kelayakan, konstruksi, penambangan, pengolahan dan pemurnian, pengangkutan dan penjualan, serta kegiatan pasca tambang. pemerintah memiliki kewenangan dalam pengelolaan pertambangan namun dalam pelaksanaannya, pemerintah sendiri sebenarnya tidak mampu untuk melakukan usaha pertambangan atas sumber daya alam tersebut. Sehingga Untuk melaksanakan kegiatan tersebut pemerintah memberikan kewenangan kepada pihak lainnya untuk dapat melakukan usaha pertambangan atas sumber daya alam tambang. Kehadiran
\end{abstract}


Kehadiran Undang 11 Tahun 2020 tentang Cipta Kerja diharapkan menjadi jalan keluar terutama terkait persoalan perizinanan dan birokrasi yang berbelit dan tumpang tindih. Tujuan penulisan untuk mengetahui bagaimana Pengelolaan usaha pertambangan mineral dan batubara pasca berlakunya undang-undang nomor 11 tahun 2020 tentang Cipta Kerja, dan dampak Pengelolaan usaha pertambangan mineral dan batubara pasca berlakunya undang-undang nomor 11 tahun 2020 tentang Cipta Kerja. Penelitian ini merupakan penelitian hukum normatif yang menggunakan bahan-bahan hukum dan bahan-bahan non hukum dengan menggunakan metode pendekatan peraturan perundang-undangan serta pendekatan konseptual dan menghasilkan kajian yang bersifat deskriptif analitis. Disimpulkan bahwa Usaha pertambangan sendiri dilaksanakan berdasarkan perizinan berusaha dari pemerintah pusat yang mana perizinan berusaha tersebut dilaksanakan melalui pemberian nomor induk berusaha, sertifikat standar dan juga izin. Adapun dampak dari dampak Pengelolaan usaha pertambangan mineral dan batubara pasca berlakunya undang-undang nomor 11 tahun 2020 tentang Cipta Kerja antara lain berdampak pada lingkungan hidup dan sosial.

Kata Kunci: usaha pertambangan, lingkungan hidup, sosial

\section{Pendahuluan}

\subsection{Latar Belakang}

Sumber daya alam mineral dan batubara merupakan kekayaan alam Indonesia, kekayaan alam ini bukanlah buatan manusia melainkan kekayaan alam yang merupakan pemberian dari Allah SWT, oleh sebab itu manusia dibebankan suatu tanggungjawab untuk dapat mengelola dan memanfaatkannya untuk kepentingan umat manusia. ${ }^{1}$ Pemerintah Indonesia sendiri memiliki kewenangan untuk menguasai sumber daya alam mineral dan batubara, sesuai Pasal 33 ayat (3) UUD 1945, bahwa bumi dan air dan kekayaan alam yang terkandung didalamnya dikuasai oleh negara dan dipergunakan untuk sebesar-besarnya kemakmuran rakyat. ${ }^{2}$ Pada tahun 2020, Pemerintah Indonesia menerbitkan 2 (dua) legislasi yang menuai banyak reaksi dari berbagai kalangan, antara lain Undang-undang Nomor 3 Tahun 2020 tentang Perubahan atas Undang-undang Nomor 4 Tahun 2009 tentang Pertambangan Mineral dan Batu Bara (selanjutnya Revisi UU Minerba) serta Undang-undang Nomor 11 Tahun 2020 tentang Cipta Kerja (selanjutnya UUCK). ${ }^{3}$ Pertambangan sendiri merupakan suatu bidang usaha yang karena sifat kegiatannya pada dasarnya selalu menimbulkan dampak pada alam lingkungannya. ${ }^{4}$

Pertambangan merupakan sebagian atau seluruh tahapan kegiatan dalam rangka

${ }^{1}$ Hayatul Ismi. (2014). Hak Atas Tanah Dalam Pengelolaan Sumber Daya Alam Mineral Dan Batubara. Jurnal Ilmu Hukum, 4 (2), 242-252. doi: org/10.30652/jih.v4i2.2792, h. 242.

2 Lihat Pasal 33 ayat 3 Undang-Undang Dasar Negara Republik Indonesia Tahun 1945

3 Ria Maya Sari. (2021). Potensi Perampasan Wilayah Masyarakat Hukum Adat Dalam UndangUndang Nomor 11 Tahun 2020 Tentang Cipta Kerja. Mulawarman Law Review, 6 (1). 1-14, doi: org/10.30872/mulrev.v6i1.506, h. 1.

4 Luthfi Hidayat. (2017). Pengelolaan Lingkungan Areal Tambang Batubara (Studi Kasus Pengelolaan Air Asam Tambang (Acid Mining Drainage) Di Pt. Bhumi Rantau Energi Kabupaten Tapin Kalimantan Selatan). Jurnal ADHUM, 7 (1). 44-52, h. 44. 
penelitian, pengelolaan, dan pengusahaan mineral atau batubara yang meliputi penyelidikan umum, eksplorasi, studi kelayakan, konstruksi, penambangan, pengolahan dan pemurnian, pengangkutan dan penjualan, serta kegiatan pasca tambang. ${ }^{5}$ Aktivitas penambangan selalu membawa dua sisi, sisi pertama adalah memacu kemakmuran ekonomi negara dan sisi yang lain adalah timbulnya dampak lingkungan. ${ }^{6}$ Salah satu komoditi yang banyak diusahakan saat ini, untuk memenuhi kebutuhan energi di Indonesia adalah batubara. Indonesia memiliki potensi sumber daya batubara sekitar 60 miliar ton dengan cadangan 7 miliar ton. ${ }^{7}$ Dengan potensi yang sebanyak itu tentu diperlukan pengelolaan secara efisen.

Pertambangan merupakan sektor yang mendapat perhatian serius dari pemerintah, mengingat kegiatan usaha pertambangan tersebut memberikan kontribusi yang cukup besar bagi masuknya devisa negara, hal ini terlihat dengan banyaknya perizinan Kuasa Pertambangan di daerah. ${ }^{8}$ Disisi lain dengan meningkatnya jumlah kegiatan usaha pertambangan baik yang melibatkan investasi asing maupun nasional, menimbulkan eksploitasi besar-besaran dan mengakibatkan pencemaran serta rusaknya lingkungan. ${ }^{9}$

Penguasaan negara dalam pengelolaan pertambangan dilaksanakan oleh Pemerintah, dalam hal ini yang dimaksud pemerintah adalah pemerintah pusat. ${ }^{10}$ Meskipun pemerintah memiliki kewenangan dalam pengelolaan pertambangan namun dalam pelaksanaannya, pemerintah sendiri sebenarnya tidak mampu untuk melakukan usaha pertambangan atas sumber daya alam tersebut. ${ }^{11}$ Sehingga Untuk melaksanakan kegiatan tersebut pemerintah memberikan kewenangan kepada pihak lainnya untuk dapat melakukan usaha pertambangan atas sumber daya alam tambang. Regulasi pertambangan sendiri memberikan wewenang kepada orang atau badan usaha untuk melakukan usaha pertambangan atas sumber daya alam tambang yang dimiliki negara Indonesia. ${ }^{12}$ Pemerintah selanjutnya memberikan kesempatan kepada badan usaha yang berbadan hukum Indonesia, koperasi, perseorangan, maupun masyarakat setempat untuk

${ }^{5}$ Hudriyah Mundzir, Sri Hudiarini, \& Shohib Muslim. (2016). Politik Hukum Pengelolaan Pertambangan Mineral Dan Batubara Dengan Pendekatan Economic Analysis Of Law, Prosiding SENTIA, 8.16-22, h. 22.

${ }^{6}$ Luthfi Hidayat, Loc. Cit.

7 Ibid, h. 44.

8 Dewi Tuti Muryati, B. Rini Heryanti, \& Dhian Indah Astanti. (2016). Pengaturan Kegiatan Usaha Pertambangan Dalam Kaitannya Dengan Penyelesaian Sengketa Pertambangan. Jurnal Dinamika Sosial Budaya, 18 (1). 23-38. h. 24.

${ }^{9} \mathrm{Ibid}, \mathrm{h} .24$.

${ }_{10}$ Lihat Pasal 4 ayat 1 Undang-Undang Nomor 3 Tahun 2020 tentang Perubahan Atas Undang-Undang Nomor 4 Tahun 2009 Tentang Pertambangan Mineral Dan Batubara

${ }^{11}$ M. Iqbal Asnawi. (2019). Implikasi Yuridis Pengelolaan Pertambangan Dalam Aspek Kehidupan Sosial Ekonomi Masyarakat. Jurnal Hukum Samudra Keadilan, 14 (1). 45-60, Doi: org/10.33059/jhsk.v14i1.909. h. 49.

12 Ibid, h. 49 
melakukan pengusahaan mineral dan batubara berdasarkan izin. ${ }^{13}$

Lahirnya Undang-Undang Nomor 3 Tahun 2020 tentang Perubahan Atas UndangUndang Nomor 4 Tahun 2009 Tentang Pertambangan Mineral Dan Batubara yang kemudian diubah kembali menjadi Undang-Undang Nomor 11 Tahun 2020 tentang Cipta Kerja tidak terlepas dari politik hukum yang merupakan pilihan tentang hukum yang akan dicabut atau diberlakukan yang kesemuanya dimaksudkan untuk mencapai tujuan negara seperti yang tercantum di dalam pembukaan UUD 1945.14

\subsection{Rumusan Masalah}

Sebagai pijakan dan sekaligus juga sebagai pembatasan dalam pembahasan tulisan ini dikemukan rumusan masalah sebagai berikut:

1. Bagaimana pengelolaan usaha pertambangan mineral dan batubara pasca berlakunya undang-undang nomor 11 tahun 2020 tentang Cipta Kerja?

2. Bagaimana dampak pengelolaan usaha pertambangan mineral dan batubara pasca berlakunya undang-undang nomor 11 tahun 2020 tentang Cipta Kerja?

\section{Metode Penelitian}

Penelitian ini merupakan penelitian hukum normatif yang menggunakan bahanbahan hukum dan bahan-bahan non hukum dengan menggunakan metode pendekatan peraturan perundang-undangan serta pendekatan konseptual dan menghasilkan kajian yang bersifat deskriptif analitis.

\section{Hasil dan Pembahasan}

\subsection{Pengelolaan Usaha Pertambangan Mineral Dan Batubara Pasca Berlakunya} Undang-Undang Nomor 11 Tahun 2020 Tentang Cipta Kerja

Pengelolaan usaha pertambangan merupakan kegiatan dalam rangka pengusahaan Mineral atau Batubara yang meliputi tahapan kegiatan penyelidikan umum, eksplorasi, studi kelayakan, konstruksi, penambangan, pengolahan dan/atau pemurnian atau pengembangan dan/atau pemanfaatan, pengangkutan dan penjualan, serta pascatambang. ${ }^{15}$ Pengelolaan usaha pertambangan sendiri sebelumnya diatur di dalam Undang-Undang Nomor 4 Tahun 2009 tentang Pertambangan Mineral dan batubara yang kemudian diubah menjadi Undang-Undang Nomor 3 Tahun 2020 tentang Perubahan Atas Undang-Undang Nomor 4 Tahun 2009 Tentang Pertambangan Mineral Dan Batubara. Perubahan peraturan tersebut tidak terlepas dari politik sebagaimana yang disampaikan

${ }^{13}$ Ibid, h. 49

${ }^{14}$ Muhammad Akib. (2016). Politik Hukum Lingkungan Dinamika Dan Refleksinya Dalam Produk Hukum Otonomi Daerah, Jakarta: PT RajaGarfindo Persada, hlm. 5

${ }^{15}$ Lihat Pasal 1 Ayat 6 Peraturan Pemerintah Republik Indonesia Nomor 96 Tahun 2021 tentang Pelaksanaan Kegiatan Usaha Pertambangan Mineral Dan Batubara 
oleh Andrew Heywood bahwa Politik adalah kegiatan suatu bangsa yang bertujuan untuk membuat, mempertahankan, dan mengamandemen peraturan-peraturan umum yang mengatur kehidupannya, yang berarti tidak dapat terlepas dari gejala konflik dan kerja sama (Politics is the activity through which a people make, preserve and amend the general rules under which they live and as such is inextricaly linked to the phenomen of conlict and cooperation). ${ }^{16}$

Perubahan Undang-Undang Nomor 4 Tahun 2009 tentang Pertambangan Mineral dan batubara didasari bahwa peraturan tersebut masih belum dapat menjawab perkembangan, permasalahan, dan kebutuhan hukum dalam penyelenggaraan pertambangan mineral dan batubara, sehingga perlu dilakukan perubahan agar dapat menjadi dasar hukum yang efektif, efisien, dan komprehensif dalam penyelenggaraan pertambangan mineral dan batubara. ${ }^{17}$

Kewenangan pengelolaan pertambangan mineral dan batubara mengalami pergeseran dimana jika mengacu pada Pasal 6, Pasal 7 dan Pasal 8 Undang-Undang Nomor 4 Tahun 2009 tentang Pertambangan Mineral dan Batubara, dalam pengelolaannya terbagi menjadi kewenangan pemerintah pusat, pemerintah daerah provinsi, dan pemerintah daerah kabupaten kota. Namun setelah lahirnya Undang-Undang Nomor 3 Tahun 2020 tentang Perubahan Atas Undang-Undang Nomor 4 Tahun 2009 Tentang Pertambangan Mineral Dan Batubara, kewenangan pengelolaan pertambangan justru bersifat sentralistik yang mana kewenangannya ada pada pemerintah pusat.

Kehadiran Undang Nomor 11 Tahun 2020 tentang Cipta Kerja atau yang biasa disebut omnibus law. Secara historis, praktik penerapan Omnibus Law banyak diterapkan diberbagai negara Common Law System, dengan tujuan untuk memperbaiki atau menyederhanakan regulasi di negaranya masing-masing dalam rangka meningkatkan iklim dan daya saing investasi. Secara umum Omnibus Law belum populer di Indonesia. ${ }^{18}$ Omnibus Law merupakan metode yang digunakan untuk mengganti dan/atau mencabut beberapa materi hukum dalam berbagai undang-undang, dimana konsekuensi dengan penerapan Omnibus Law adalah 1) UU existing masih tetap berlaku, kecuali sebagian pasal (materi hukum) yang telah diganti atau dinyatakan tidak berlaku; 2) UU existing tidak diberlakukan lagi, apabila pasal (materi hukum) yang diganti atau dinyatakan tidak berlaku merupakan inti/ruh dari undang-undang tersebut. ${ }^{19}$

Kehadiran Undang 11 Tahun 2020 tentang Cipta Kerja diharapkan menjadi jalan 16.

${ }^{16}$ Miriam Budiardjo. (2008). Dasar-Dasar Ilmu Politik, Jakarta: Gramedia Pustaka Utama, hlm.

17 Lihat Konsiderans huruf C Undang-Undang Nomor 3 Tahun 2020 Perubahan Atas Undang-Undang Nomor 4 Tahun 2009 Tentang Pertambangan Mineral Dan Batubara

18 Dhaniswara K. Harjono. (2020). Konsep Omnibus Law Ditinjau Dari Undang Undang No. 12 Tahun 2011 Tentang Pembentukan Peraturan Perundang Undangan. Jurnal Hukum: Hukum Untuk Mengatur Dan Melindungi Masyarakat, 6 (2). 96-110. doi : org/10.33541/JtVol5Iss2pp102. h. 98.

${ }^{19} \mathrm{Ibid}$, h. 99 
keluar terutama terkait persoalan perizinanan dan birokrasi yang berbelit dan tumpang tindih. Managing Partner Adisuryo Dwinanto \& Co, Dendi Adisurya, menjelaskan bahwa setidaknya terdapat tujuh permasalahan utama di bidang mineral dan batubara: ${ }^{20}$

(1) Overdosis izin dan tumpang tindih perizinan daerah dan sektoral. Saat ini untuk mengurus perizinnan sektor minerba, jumlah izin yang harus dimiliki oleh perusahaan tambang sebelum memulai kegiatan pertambangan sangat banyak dan kompleks. Ditambah lagi adanya tumpang tindih kewenangan antara daerah dan pusat dan antar department;

(2) Perubahan rezim ke Izin Usaha Pertambangan (IUP). Persoalan muncul saat implementasi kewajiban konversi dari kontrak ke izin, dan negotiated items penyesuaian kontrak menjadi izin meliputi luas wilayah, divestasi, lokal konten, penerimaan negara dan nilai tambah;

(3) Konflik pembebasan. Di mana penyelesaian dilakukan Business to Business, adanya konflik antar jenis konsesi, dan tidak ada pengaturan mengenai pembebasan lahan untuk kepentingan industri pertambangan;

(4) Hilirisasi. Persoalan terkait On and off larangan ekspor ore, realisasi pembangunan smelter di 2021 seperti jumlah izin smelter;

(5) Divestiasi saham bagi investasi asing. Masalah yang muncul seputar disinsentif investasi asing, nilai divestasi saham - dihitung berdasarkan fair market value, dengan metode discounted cash flow dan/atau perbandingan data pasar (Pasal 14 Permen ESDM 07/2017 dan 43/2018), dan kesiapan BUMN/BUMD untuk membeli divested shares;

(6) Adanya stagnansi pertumbuhan cadangan minerba, risiko investasi yang tinggi di tahap eksplorasi, pemerintah tidak memiliki exploration funds yang memadai, dan insentif eksplorasi;

(7) Penerbitan izin usaha baru terutama terkait implementasi lelang (Wilayah Izin Usaha Pertambangan (WIUP).

Pertambangan Mineral dan Batubara sendiri dikelompokkan ke dalam 5 (lima) golongan antara lain:21

(1) Mineral radioaktif meliputi uranium, torium, dan bahan galian radioaktif lainnya;

(2) Mineral logam meliputi aluminium, antimoni, arsenik, basnasit, bauksit,

${ }^{20}$ Hukumonline.com. 7 Masalah utama di bidang minerba sebelum adanya UU Cipta Kerja. Available from https://www.hukumonline.com/berita/baca/lt601a5c1ef320a/7-masalah-utamadi-bidang-minerba-sebelum-adanya-uu-cipta-kerja/?page=4, (Diakses 10 Desember 2020).

${ }^{21}$ Lihat Pasal 2 Ayat 1 Peraturan Pemerintah Republik Indonesia Nomor 96 Tahun 2021 tentang Pelaksanaan Kegiatan Usaha Pertambangan Mineral Dan Batubara 
berilium, bijih besi, bismut, cadrnium, cesium, emas, galena, galium, germanium. hafnium, indium, iridium, khrom, kcbai, kromit, litium, logam tanah jarang, magnesium, mangan, moiibdenum, monasit, nikel, niobium, osmium, pasir besi, palladium, perak, platina, rhodium, ruthenium, selenium, seng, senodm, sinabar, stroniurn, tantalum, telurium, tembaga, timah, titanium, vanadium, wolfram, dan zirkonium;

(3) Mineral bukan logam meliputi asbes, barit, belerang, bentonit, bromium, dolomit, feldspar, fluorit, fluorspar, fosfat, garam batu, gipsum, gratlt, halit, ilmenit, ktrlsit, kaolin, kriolit, kapur padam, kuarsit, magnesit, mika, oker, perlit, pirofilit, rijang, rutil, talk, tawas, rvolasfonit, yarosit, yodiurn, zeolit, dan zirkon;

(4) batuan meliputi agar, andesit, basalt, batu apung, batu gamping, batu gunung kuari besar, batu kali, chert, diorit, gabro, garnet, giok, granit, granodiorit, jasper, kalsedon, kayu terkersikan, kerikil berpasir alami (sirtu), kerikil galian dari bukit, ker:ikil sungai, kerikil sungai ayak tanpa pasir, krisoprase, kristal kuarsa, leusit, marmer, obsidian, onik, opal, pasir laut, pasir urug, pasir pasang, perlit, peridotit, pumice, tanah, tanah diatome, tanah liat, tanah merah, tanah serap, tanah urug, toseki, trakhit, tras, slate, dan pasir yang tidak mengandung unsur Mineral logam atau unsur Mineral bukan logam dalam jumlah yang berarti ditinjau dari segi ekonomi Pertambangan; dan

(5) Batubara meliputi batuan aspal, batubara, biturmen padat, dan gambut.

Usaha pertambangan sendiri dilaksanakan berdasarkan perizinan berusaha dari pemerintah pusat yang mana perizinan berusaha tersebut dilaksanakan melalui pemberian nomor induk berusaha, sertifikat standar dan juga izin. Kemudian Mengenai izin sendiri terdiri dari beberapa aspek mulai dari izin usaha pertambangan, izin usaha pertambangan khusus, IUPK sebagai Kelanjutan Operasi Kontrak/Perjanjian, Izin Pertambangan Rakyat, Surat Izin Penambangan Batuan, izin penugasan, Izin Pengangkutan dan Penjualan, Izin Usaha Jasa Pertambangan, dan IUP untuk Penjualan.22

Mengenai izin usaha pertambangan terdiri atas dua tahap kegiatan yakni, eksplorasi yang meliputi kegiatan penyelidikan umum, eksplorasi, dan studi kelayakan. Serta operasi produksi yang meliputi kegiatan Konstruksi, Penambangan, Pengolahan, Pemurnian, Pengembangan atau Pemanfaatan, serta Pengangkutan dan Penjualan. ${ }^{23}$ Dalam pengelolaannya izin usaha pertambangan sendiri diberikan kepada Badan Usaha, Koperasi, dan Perusahaan Perorangan.

${ }^{22}$ Lihat Pasal 6 Ayat 4 Peraturan Pemerintah Republik Indonesia Nomor 96 Tahun 2021 tentang Pelaksanaan Kegiatan Usaha Pertambangan Mineral Dan Batubara

${ }^{23}$ Lihat Pasal 36 ayat 1 Undang-Undang Nomor 3 Tahun 2020 tentang Perubahan Atas Undang-Undang Nomor 4 Tahun 2009 Tentang Pertambangan Mineral Dan Batubara 


\subsection{Dampak Pengelolaan Usaha Pertambangan Mineral Dan Batubara Pasca Berlakunya Undang-Undang Nomor 11 Tahun 2020 Tentang Cipta Kerja \\ 3.2.1 Lingkungan Hidup}

Secara umum usaha pertambangan mineral dan batubara mempunyai peranan penting dalam memberikan nilai tambah secara nyata terhadap pendapatan nasional dan pembangunan daerah terkait permintaan global akan batubara sebagai sumber energi alternatif untuk mencukupi kebuhan energi seiring dengan meningkatnya harga bahan bakar minyak bumi. ${ }^{24}$ Namun yang tidak bisa diabaikan adalah kegiatan pertambangan sering kali menjadi salah satu penyebab kerusakan lingkungan hidup disamping bentuk eksploitasi lingkungan lainnya seperti pembukaan lahan (open pit), hilangnya biota tumbuhan, penebangan pohon yang mana berfungsi sebagai penyokong cadangan air, mengganggu koridor hewan dalam habitat aslinya, serta belum lagi limbah yang dihasilkan penyebab pencemaran tanah dan air. ${ }^{25}$

Permasalahan tersebut melahirkan sebuah kesadaran lingkungan akan pentingnya perhatian dan kepedulian (concern) terhadap lingkungan hidup sebagai akibat terjadinya berbagai masalah lingkungan terutama di sektor pertambangan mineral dan batubara. ${ }^{26}$ Undang-Undang Minerba khususnya Undang-Undang Nomor 11 Tahun tentang Cipta Kerja memang dinilai lebih bermuatan pada resource used oriented law atau menitik beratkan pada aspek pemanfaatan sumber daya dan lingkungannya sehingga minim muatan hukum yang pro-ekologis, Kehadiran undang-undang minerba tersebut memberikan ruang gerak dalam rangka pemanfaatan kekayaan mineral, meskipun di dalamnya diatur aspek-aspek penting dalam tahapan kegiatan pertambangan namun sedikit menyinggung unsur perlindungan lingkungan. ${ }^{27}$ Dalam hal ini peran politik hukum lingkungan dibutuhkan sebagai kelestarian fungsi dan daya dukung atau daya tampung lingkungan serta tetap memperhatikan kesejahteraan masyarakat secara berkelanjutan.

\subsubsection{Sosial}

Dalam konteks kehidupan sosial masyarakat di sekitar lokasi pertambangan, hubungan sosial terbentuk karena kesamaan kepentingan di atas pengelolaan sumbersumber produksi setempat, kesamaan atas tanah dan kekayaan alam, serta kesamaan

${ }^{24}$ Hemi Faradila. (2020). Izin Usaha Pertambangan Mineral Dan Batubara Dalam Kaitan Dengan Pengelolaan Dan Perlindungan Lingkungan Hidup (Fiqh Al-Bi'ah). Jurnal MUDARRISUNA, 11 (3). 519525. doi: org/10.22373/jm.v10i3.7888, h. 520.

${ }^{25} \mathrm{Ibid}$, h. 520

${ }^{26}$ Muhammad Akib. (2016). Hukum Lingkungan Perspektif Global dan Nasional, Jakarta, PT Raja Garfindo Persada, h. 11

${ }^{27}$ Hemi Faradila, Op. Cit., h. 522-523 
sejarah dan adat budaya. Direnggutnya penguasaan masyarakat atas tanah dan kekayaan alam menyebabkan fondasi modal sosial mereka lenyap. ${ }^{28}$

Keadaan ini pada umumnya akan dan berdampak terhadap: Lenyapnya daya ingat sosial, hilangnya tatanan nilai sosial yang dulunya dimiliki komunitas, Putusnya hubungan silahturami antar warga menyebabkan perpecahan, persengketaan dan bahkan ke taraf konflik (saling melenyapkan eksistensi satu sama lain). Mekanisme resolusi konflik tradisional yang telah hidup dalam komunitas tidak lagi dijadikan kontrol dalam kehidupan sosial, Menurunnya daya tahan tubuh, karena merosotnya mutu kesehatan, mental warga, dan seringkali munculnya penyakit-penyakit baru, baik penyakit yang berupa metabolisme akut akibat pencemaran (udara, air, tanah dan bahan-bahan hayati yang dikonsumsi), penyakit menular (kelamin)dan penyakit lain yang dibawa oleh pekerja yang berasal dari luar daerah. ${ }^{29}$

Selain dampak sosial, kegiatan pertambangan juga akan berdampak kepada ekonomi masyarakat di sekitar wilayah pertambangan. Operasi pertambangan membutuhkan lahan yang luas, dipenuhi dengan cara menggusur tanah milik dan wilayah kelola rakyat. Hal ini akan berdampak pada kondisi-kondisi sebagai berikut: ${ }^{30}$

(1) Kehilangan sumber produksi (tanah dan kekayaan alam) melumpuhkan kemampuan masyarakat setempat menghasilkan barang-barang dan kebutuhan mereka sendiri;

(2) Rusaknya tata konsumsi, lumpuhnya tata produksi menjadikan masyarakat makin tergantung pada barang dan jasa dari luar. Untuk kebutuhan sehari-hari mereka semakin lebih jauh dalam jeratan ekonomi. Uang tunai yang cendrung melihat tanah dan kekayaan alam sebagai faktor produksi dan bisa ditukar dengan sejumlah uang tidak lebih;

(3) Rusaknya tata distribusi, kegiatan distribusi setempat semakin didominasi oleh arus masuknya barang dan jasa ke dalam komunitas.

Selain itu perubahan Pasal 162 Undang-Undang Mineral dan Batubara yang ada di Undang-Undang Cipta Kerja dianggap bisa mengkriminalisasi masyarakat yang dianggap merintangi atau mengganggu kegiatan usaha pertambangan yang mengantongi izin. ${ }^{31}$

${ }^{28}$ M. Iqbal Asnawi, Op.Cit., h. 54.

${ }^{29} \mathrm{Ibid}, \mathrm{h} .55$

${ }^{30} \mathrm{Ibid}, \mathrm{h} .55$

${ }^{31}$ hukumonline.com, Dua Pasal UU Cipta Kerja Sektor Pertambangan Ini Dinilai Bermasalah, Available from https://m.hukumonline.com/berita/baca/lt5f8ef080e80a6/dua-pasal-uu-ciptakerja-sektor-pertambangan-ini-dinilai-bermasalah?page=all, (Diakses 9 Juli 2021) 


\section{Kesimpulan}

(1) Pengelolaan Usaha Pertambangan Mineral Dan Batubara Pasca Berlakunya Undang Undang Nomor 11 Tahun 2020 Tentang Cipta Kerja Usaha pertambangan sendiri dilaksanakan berdasarkan perizinan berusaha dari pemerintah pusat yang mana perizinan berusaha tersebut dilaksanakan melalui pemberian nomor induk berusaha, sertifikat standar dan juga izin. Mengenai izin usaha pertambangan terdiri atas dua tahap kegiatan yakni, eksplorasi yang meliputi kegiatan penyelidikan umum, eksplorasi, dan studi kelayakan. Serta operasi produksi yang meliputi kegiatan Konstruksi, Penambangan, Pengolahan, Pemurnian, Pengembangan atau Pemanfaatan, serta Pengangkutan dan Penjualan. Dalam pengelolaan usaha pertambangan izin usaha pertambangan sendiri diberikan kepada Badan Usaha, Koperasi, dan Perusahaan Perorangan.

(2) Dampak Pengelolaan usaha pertambangan mineral dan batubara pasca berlakunya undang-undang nomor 11 tahun 2020 tentang Cipta Kerja meliputi dampak terhadap lingkungan hidup dimana Kehadiran undang-undang minerba tersebut memberikan ruang gerak dalam rangka pemanfaatan kekayaan mineral, namun dalam tahapan kegiatan pertambangannya hanya sedikit menyinggung unsur perlindungan lingkungan. Kemudian dampak sosial adanya perubahan Pasal 162 berpotensi dapat mengkriminalisasi masyarakat yang dianggap merintangi atau mengganggu kegiatan usaha pertambangan yang mengantongi izin.

\section{Daftar Pustaka}

\section{A. Buku}

Akib, Muhammad. (2016). Politik Hukum Lingkungan Dinamika Dan Refleksinya Dalam Produk Hukum Otonomi Daerah, Jakarta: PT Raja Garfindo Persada. (2016). Hukum Lingkungan Perspektif Global dan Nasional, Jakarta: PT Raja Garfindo Persada.

Budiardjo, Miriam. (2008). Dasar-Dasar Ilmu Politik, Jakarta: Gramedia Pustaka Utama.

\section{B. Peraturan Peundang-undangan}

Undang-Undang Dasar Negara Republik Indonesia Tahun 1945

Undang-Undang Nomor 11 Tahun 2020 tentang Cipta Kerja

Undang-Undang Nomor 3 Tahun 2020 tentang Perubahan Atas Undang-Undang Nomor 4 Tahun 2009 Tentang Pertambangan Mineral Dan Batubara

Peraturan Pemerintah Republik Indonesia Nomor 96 Tahun 2021 tentang Pelaksanaan Kegiatan Usaha Pertambangan Mineral Dan Batubara 


\section{Artikel Jurnal}

Asnawi, M. Iqbal. (2019). Implikasi Yuridis Pengelolaan Pertambangan Dalam Aspek Kehidupan Sosial Ekonomi Masyarakat. Jurnal Hukum Samudra Keadilan, 14 (1). 45-60, Doi: org/10.33059/jhsk.v14i1.909.

Astanti, Dewi Tuti Muryati, B. Rini Heryanti, Dhian Indah. (2016). Pengaturan Kegiatan Usaha Pertambangan Dalam Kaitannya Dengan Penyelesaian Sengketa Pertambangan. Jurnal Dinamika Sosial Budaya, 18 (1). 23-38.

Faradila, Hemi. (2020). Izin Usaha Pertambangan Mineral Dan Batubara Dalam Kaitan Dengan Pengelolaan Dan Perlindungan Lingkungan Hidup (Fiqh Al-Bi'ah). Jurnal MUDARRISUNA, 11 (3). 519-525. doi: org/10.22373/jm.v10i3.7888, h. 520.

Harjono, Dhaniswara K. (2020). Konsep Omnibus Law Ditinjau Dari Undang Undang No. 12 Tahun 2011 Tentang Pembentukan Peraturan Perundang Undangan. Jurnal Hukum: Hukum Untuk Mengatur Dan Melindungi Masyarakat, 6 (2). 96-110. doi: org/10.33541/JtVol5Iss2pp102.

Hidayat, Luthfi. (2017). Pengelolaan Lingkungan Areal Tambang Batubara (Studi Kasus Pengelolaan Air Asam Tambang (Acid Mining Drainage) Di Pt. Bhumi Rantau Energi Kabupaten Tapin Kalimantan Selatan). Jurnal ADHUM, 7 (1). 44-52.

Ismi, Hayatul. (2014). Hak Atas Tanah Dalam Pengelolaan Sumber Daya Alam Mineral Dan Batubara. Jurnal Ilmu Hukum, 4 (2), 242-252. doi: org/10.30652/jih.v4i2.2792,

Muslim, Hudriyah Mundzir, Sri Hudiarini, Shohib. (2016). Politik Hukum Pengelolaan Pertambangan Mineral Dan Batubara Dengan Pendekatan Economic Analysis Of Law, Prosiding SENTIA, 8.16-22

Sari, Ria Maya. (2021). Potensi Perampasan Wilayah Masyarakat Hukum Adat Dalam Undang-Undang Nomor 11 Tahun 2020 Tentang Cipta Kerja. Mulawarman Law Review ,6 (1). 1-14, doi: org/10.30872/mulrev.v6i1.506.

\section{Website Resmi}

hukumonline.com, Dua Pasal UU Cipta Kerja Sektor Pertambangan Ini Dinilai Bermasalah, Available from https://m.hukumonline.com/berita/baca/lt5f8ef080e80a6/duapasal-uu-cipta-kerja-sektor-pertambangan-ini-dinilai-bermasalah?page=all, (Diakses 9 Juli 2021)

Hukumonline.com. 7 Masalah utama di bidang minerba sebelum adanya UU Cipta Kerja. Available from https://www.hukumonline.com/berita/baca/lt601a5c1ef320a/7masalah-utama-di-bidang-minerba-sebelum-adanya-uu-cipta-kerja/ ?page=4

(Diakses 10 Desember 2020). 